\section{ONOMÁVAEIN}

Journal of linguistics, philology and translation
PONTIFICIA UNIVERSIDAD CATÓLICA DE CHILE FACULTAD DE LETRAS

\title{
Simplification in subtitling filmic Beijing Opera
}

\section{Yilei Yuan}

Zhejiang International Studies University

China

\section{Duoxiu Qian}

Beihang University

China

ONOMÁZEIN 53 (September 2021): 42-60

DOI: 10.7764/onomazein.53.04

ISSN: $0718-5758$

\section{(c) $\underset{\mathrm{BY}}{(\mathrm{i})} \bigodot_{\mathrm{ND}}$}

Yilei Yuan: School of Applied Foreign Languages, Zhejiang International Studies University, China.

| E-mail: yileiyuan@zisu.edu.cn

Duoxiu Qian: School of Foreign Languages, Beihang University, China. | E-mail: qianduoxiu@buaa.edu.cn 


\section{Abstract}

In recent years, opera translation and surtitling has become a field of growing popularity in translation studies. While current research often revolves around opera in the western countries or opera translation for the stage, this paper aims to explore the translation of Beijing Opera in films. The discussion will draw upon literature on opera translation and surtitles while examining Beijing Opera. With reference to Raise the Red Lantern (1991), directed by Zhang Yimou, an internationally acclaimed filmmaker, this paper will focus on the rendition of Beijing Opera and propose subtitles for an opera sequence in the film. The major finding is that it is possible to convey the general meaning of the lyrics of Beijing Opera through simplification, i.e. culturally-bound references could be simplified for better understanding. This is an addition to the existing research on translation from other languages into English and will have implications for future practices in this domain.

Keywords: opera translation; surtitling; Beijing Opera; subtitling; simplification. 


\section{Surtitle and its translation: an introduction}

In Europe, during the first half of the twentieth century, opera was predominantly performed in the vernacular owing to strengthened feelings of national identity by wars, greater understanding of the text, engagement and communication (Palmer, 2013: 22). The trend continued to the 1960 s and 1970 (ibid.). In 1983, the Canadian Opera Company allegedly first used surtitles which were projected onto a screen above the stage (Low, 2002: 97; Bosseaux, 2011: 192; Lunden, 2018). It is also stated that the first live titles in an opera house were in Beijing in 1983, although there are reports of live surtitling in Copenhagen before this date and at New York City Opera at about the same time (Burton, 2010: 180). According to Bataillon (2017: 626), the era of captioning officially began in July 1996 at the Municipal Theatre of Avignon. In recent years, performing opera in a source language (SL) or in any audience's language has been a major discussion topic in the literature of translation studies. Nisato (1999, quoted in Orero \& Matamala, 2007: 262) summarises three possibilities in opera performance, including performing it in the original language and providing either a synopsis or translated libretto, performing in the original language and giving surtitles, or performing a sung translation of the work. Among these, surtitling, specifically, can be a complex interlingual transfer between different cultures and between oral and written words (Griesel, 2009: 122). Surtitling can also be defined as 'written, additive, immediate, synchronous and polymedial translation' (Gottlieb, 1997, quoted in Mateo, 2007: 136) and, like other audiovisual translation types, stems from a reception necessity (Mateo, 2007: 136). It is about rendering an audiovisual text, a semiotic composition with various semiotic systems operating simultaneously through both visual and acoustic channels in verbal and non-verbal codes (Rędzioch-Korkuz, 2018: 226).

\subsection{Surtitles as a form of opera translation}

Surtitles were first created as target texts (TT) to facilitate comprehension of the opera's plot with a very discrete presence at the theatre, which were never meant to replace the source text (ST), but to complement it (Mateo, 2007: 137). However, according to Christiansen (2005), surtitles are only a reasonable compromise to an impossible dilemma but not a solution:

Surtitles aren't marvels. I hate, for instance, their inability to synchronise with the words coming out of the singers' mouths, often creating disconcerting time lapses. They also present problems of literalism: should they relay every word, or should they précis?

Surtitles distract attention from the stage and tend to appear ugly and jar visually (Palmer, 2013: 24). Despite all the flaws and challenges, surtitled opera has become more popular since a few years ago, perhaps because it is cheaper than singable translations (Mateo, 2007: 141). In opera houses nowadays, various surtitling systems are currently in use, although without an internationally agreed "standard" system (Burton, 2010: 180-181). Titles can be projected on screen either from slides or electronically via a digital projector, or with presentation software such as PowerPoint (ibid.). Various types of LED screens are provided 
in different venues, some with brightness, fading and colour options adjustable (ibid.). Furthermore, PowerPoint has particularly corrected the rigidity of earlier computer systems for specifics such as the number of lines per title and of characters per line, and the conventions of punctuation marks in each language (Mateo, 2007: 143). Torticoli is a kind of surtitle software that can process both TXT and WORD documents; compatible with LED panels and video projectors, it can produce four lines on a central screen or split them for side screens (Bataillon et al., 2016: 47). Opus, developed from Torticoli, can detect, for instance, long lines of titles and offsetting, and display the ST and the TT side by side (Bataillon, 2017: 628, 631). Furthermore, seatback screens powered by Met Titles, which is developed by the New York Metropolitan Opera, have become common in some countries, too. Met Titles, a custom-designed system for simultaneous translation, provide titles in English, Spanish, German and Italian (The Metropolitan Opera, 2019). In the future, multimedia glasses that can screen captions may also be introduced in opera houses.

If the technological aspect of surtitling is visible, the reality and the profession of it might not be. The translator of the libretto who provides the translated text and the surtitler who cues surtitles during the performance can be two different professions (Desblache, 2019: 326). Undoubtedly, theatres in different countries more or less operate differently. According to Bataillon (2017: 632), in live surtitling, a variety of decisions are often involved with regard to the form, location and rhythm of surtitles, all of which need to be discussed with the director, possibly before the performance. To work with modern software such as Opus, surtitle writing and play text cutting require meticulous operation, making the cost rise (ibid.), which is somewhat against the purpose of budgeting. Time invested into surtitling might be deemed disproportionate, too; one performance for only a few nights sometimes requests two months' surtitle preparation (ibid.).

\subsection{Surtitle translation in practice}

Although surtitles are increasingly acceptable in various parts of the world, the translation of them seems to be eternally doubted and the challenges in this task unquestionable. To Richard Wagner (1813-1883), the greatest musico-dramatic genius of his time, the manifold sins committed against the world-music synthesis and the trials and tribulations suffered by opera translators proficient in language yet ignorant of music have been the target of bitter criticism (Gorlée, 1996: 407). More specifically, to Mackerras (1991, quoted in Griesel, 2009: 124), although it will never be sung, the translation of librettos into surtitles may have to meet the requirements of singableness and should guarantee a fast reception, which consists of simple sentence structures and form complete unities. Furthermore, the words to which composers set music are crucially important too, especially in opera, where the words are an intrinsic element (Dewolf, 2001: 182). This is not only in the expression of the meaning sung, but of the dramatic action, and not only the words, but syllables, inflections, accents, rise, fall and emphasis (ibid.). By contrast, Pridmore-Franz (2015: 64-65) argues that a dichotomy lies be- 
tween two possibilities of surtitling, to preserve the cultural, linguistic and artistic elements of the ST at the cost of other semiotic aspects of an opera, or to prioritise representation by reducing the ST. Page (2013: 44) also maintains that, compared to the transfer of meaning, the transmission of form, delivery and style is not as paramount.

On the other hand, the integration of music and librettos in opera also results in the question of what the ST is for surtitling and opera translation. Virkkunen (2004: 95) maintains that the ST should be a complete stage performance rather than the libretto per se, as words are inseparable from music with regard to an opera. Operas as audiovisual texts are not autonomous entities but have to be interpreted in the multisemiotic complex, the production of which is marked by the need for efficiency and for coherence and synchronisation with all other elements (Mateo, 2007: 135-136). Therefore, when translating a song in an opera, a multimodal analysis is essential where verbal, non-verbal, visual and auditory signs are taken into account altogether, and the text or libretto as well as the context or other semiotic modes have to be both considered (Bosseaux, 2011: 193). Also, consulting the original source works may be helpful, according to professional opera surtitlers (Burton, 2010: 183; Palmer, 2013: 27), as many opera librettos are based on existing plays or novels, though the original may not exist anymore. The motivations or relationships of the characters may be clearer in the source work than in the libretto set by the composer, making an understanding of the historical background conducive to the translator's task and the audience's comprehension (Burton, 2010: 183).

However, some surtitlers might have taken their tasks too far. In Francophone Canada, cases of playful surtitles appeared, which consisted of a string of symbols or a warning that no surtitles would be provided for the oncoming stage speeches (Ladouceur, 2013: 355-356). Ladouceur (2013: 357) contends that the playful surtitles are able to create new messages, through the translator's voice speaking directly to the audience through critical or ironic comments on the performance. This seems to oppose the ultimate purpose of adopting surtitles, which is to facilitate communication between performers and audiences without causing unnecessary distraction. A surtitled performance should be assessed in regard to its usability, accessibility or relevance, which means unobtrusiveness and the necessity to make the performance intelligible is the intrinsic goal of surtitling (Rędzioch-Korkuz, 2018: 223).

The expectation of surtitles to be unobtrusive makes surtitling a "dangerous" practice, whereas the seemingly precariousness is complicated by a human factor, i.e. the behaviour of performers, or incidental mistakes that could be made during a performance (Rędzioch-Korkuz, 2018: 221). A certain degree of improvisation can also occur, while a play can be changed in the last minute (Scorcia, 2018: 183). This means surtitles are prone to changes even after the play has been performed (Oncins, 2013: 58).

Either for surtitlers' creative experimentation or for actors' improvisation, surtitling is replete with solutions as well as challenges. Two of the previously mentioned difficulties are how to 
balance music and words and how to prioritise meaning over style. The truth is that retaining the meaning, the culture and the style all at once should be undoubtedly challenging, if not impossible at all. Even if the singing speed allows a surtitle more time, space can still be a constraint. Also, audiences are always varied, some of whom may be bilingual and find surtitles unsightly or distracting. Others can be monolingual and in great need of surtitles, hoping them to be concise and faithfully translated. After all, surtitles are an aid to guarantee accessibility to a wider audience but are distinct from the performance itself. Because of the impossibility of assisting everyone, surtitles merely need to be briefly and directly translated and return audiences to the stage, instead of "stealing the show".

Given that every performance can be different from the day before or after due to improvisation, rhythm or mistakes, filming it and providing subtitles can eradicate uncertainties of the ST. An operatic film, surely a different experience, can reach a larger audience while keeping a record of the art, which is similar to musicals or theatre on TV. One subtitler will be needed instead of a translator of the libretto and a surtitler. In recent years, China has started to film Beijing Opera with English closed captioning, some in 3D too.

After summarising the existence and translation of surtitles, we will provide a summary of research on Beijing Opera and its translation in the following part.

\section{Beijing Opera}

In 1985, a crew of Jingju (Beijing Opera) Theater Company of Beijing travelled to Warsaw and London to perform a Beijing Opera entitled 三打陶三春 (sān dă táo sān chūn) or Three Combats with Sanchun Tao (the authors' translation) (Wang, 1985). When the crew expressed their wish to provide subtitles for their performance at a theatre festival in London, the organisers denied it, even after rounds of communication (ibid., cf. Mateo, 2007: 138). Interestingly, the London audience, without any translation, laughed, nodded, applauded as the performance progressed, and even compared it with Shakespearian comedies and those of Charlie Chaplin's (Wang, 1985).

Literally speaking, "Beijing Opera” means 'the opera of Beijing', which explains why it is also referred to as "Peking Opera". "Peking" is the former Wade-Giles Romanisation of the name of this capital city, whereas "Beijing" is the Pinyin spelling used in China nowadays to demonstrate the Mandarin pronunciation of Chinese characters. Beijing Opera, which fully developed in the eighteenth century, became well received in the nineteenth century (Guo, 2012: 51). Combining music, vocalisation, impersonation, dancing and acrobatics, it is the most representative and influential Chinese Opera (ibid.). It boasts of four major types of roles, 生 (shēng, male), 트 (dàn, female), 净 (jìng, painted-face) and \#丑 (chŏu, comedian), while each type has sub-types (ibid.: 52). 


\subsection{The translation of Beijing Opera}

By drawing upon his experiences in translating 李笠翁曲话 (li lì wēng qŭ huà) or Li Yu’s Essays on Classical Drama, Zhu (2006: 48) summarises four steps for the translation of Chinese classics, which may also be applicable in Beijing Opera translation:

1. Identify the significance of the ST in the source culture.

2. Know if the ST has been translated into the target language ( $\mathrm{TL}$ ) before.

3. Research the ST extensively and perform an intralingual translation if necessary.

4. Choose the translation norm for this ST while retaining flexibility. (The authors' translation).

Step 4 is presumably the central one, to identify the norm. Bassnett (2002 [1980]: 124) considers a theatre text to be read as something incomplete rather than a fully rounded unit, since its full potential can only be realised in performance. She states that linguistics may be treated with lower significance in favour of performability-related structures, if necessary (ibid.: 126). Consequently the task of the translator is to determine what those structures are and to translate them into the $\mathrm{TL}$, "even though this may lead to major shifts on the linguistic and stylistic planes" (ibid.). However, Bassnett (1998: 95) later also expresses a deep doubt on the term "performability", as there lacks a clear definition of what that is. There also exists a whole range of different ways of reading a playtext (ibid.).

Unfortunately, performability may prove to be an inapplicable norm to evaluate the quality of translated Chinese Opera; the reason is fivefold.

1. The wide existence of closet drama or 'desktop opera' in Chinese literally (案头戏, àn tóu xil), scripts that are primarily for reading purposes. To glorify performability is partly to discriminate the reading purposes of opera.

2. The variety of singing styles and dialects and the loan of stories between different operas. Performability is considered vague for the specificities of Chinese Opera.

3. The long history of independence from scripts and reliance on actors' creativity.

4. The lack of experts on both translation and direction.

5. The relatively low chances for translated opera to be re-performed (Cao, 2015:4-6). (Edited and translated by the authors).

To create a performable opera translation, many culturally-bound elements will be inescapably domesticated. A domesticated translation of a Beijing Opera text is inclined to lose elements that are crucial to operas listed as World Intangible Cultural Heritage (Cao, 2011a: 146). Nonetheless, to promote international awareness of the art is Chinese translators' 
purpose in translating opera, which makes the first and foremost norm of this task one that retains the classicalness and authenticity (ibid.: 148). In comparison, the translation of western sinologists such as Elizabeth Ann Wichmann tends to replace, recreate, adapt, add or omit parts with the view to producing texts that meet the requirements of re-performing (CaO, 2011a: 148; 2011b: 159; 2015: 130). In this type of translation, the translator replacing the ST element with an assumed TL equivalent, between whichever language pair, might be regarded as twisting the $\mathrm{ST}$, which is apt to cause misinterpretation (Ca0, 2011b: 160). Therefore, Cao (2011a: 148) argues that the translator is advised to do their utmost to preserve the poetic and aesthetic in Chinese Opera, as well as salutation vocabulary, puns, specific terms, slang, proverbs and allusions.

However, in transferring different roles of Beijing Opera into English, Zhang (2013: 41) emphasises the importance to domesticate, which is exemplified by 青衣 (qing yī, literally ‘black costume'), which often refers to a married woman, youthful or middle-aged. This role, frequently characterised as virtuous, involves much singing while the actor's body movement is slow and gentle. Therefore, Zhang expresses preference for "virtuous lady" that facilitates effective communication. Yet, mistakes have been made owing to the lack of English knowledge in this translation process (Guo, 2012: 53). For instance, 花旦 (huā dàn, literally 'flowery girl'), a young, cheerful woman, was once translated as 'flirtatious girl' or 'coquette female character' (ibid.). Moreover, certain superficial translations do not promote understanding of the characteristics of a role either. 红生 (hóng shēng), literally meaning 'red male', is known for a face painted red that represents righteousness and integrity (ibid.). If translated verbatim, this role might be interpreted as a symbol of threat and irritability instead.

\subsection{The challenges and limitations of Beijing Opera subtitling}

The international promotion of Beijing Opera largely relies on the following methods: performing it in Chinese or showing it as a film with subtitles or not, showing it with English dubbing, or performing it in a foreign language (Ca0, 2011b: 161; Xiao \& Xiong, 2016: 169-170). Subtitling which is cost-effective and less interfering is deemed as the future of the translation of Beijing Opera (CaO, 2011b: 161). At the National Centre for the Performance Arts (NCPA) in Beijing, screens display three lines of subtitles, 26 English characters maximum on each line (Dong, 2017: 134). In fact, the length of the surtitle screen is roughly $1 / 3$ of that of the stage in the biggest theatre at NCPA, which is not particularly large for audiences at the back or upstairs. Moreover, based on the authors' recent survey among major opera houses and theatres in Beijing and Shanghai, no seatback surtitling devices are installed. English surtitles are rarely provided in the surveyed venues, let alone in other non-Chinese languages, which indicates very few Chinese opera houses employ surtitlers or translators in general. Only Chinese surtitles which are mostly prepared before performances are sometimes projected on the screen(s), with the rhythm adjusted to the performance. 
The late senior Beijing Opera artist Shihai Yuan (1919-2002) held a negative view against subtitles projected on the screens on the two sides of the stage, believing that the audience is distracted from actors' performance and also blaming some actors' poor diction (Huang, 2002). Jingju Theater Company of Beijing once investigated international viewers' experiences with subtitles. Some complained that the English subtitles could roughly convey the general structure of the plotline and meaning of the lyrics and stage speeches, but failed to express the profundity of Beijing Opera, not to mention representing its poetics (Ye, 2009). The authors have also learned in a small-scale survey that although non-Chinese viewers may find some subtitles long and the poetic language rare, the plotline is fairly clear. This means that although subtitles are not flawless, undeniably, they can still fulfil the very basic function of reproducing the story in the $T L$.

Despite the alleged significance of subtitling for Beijing Opera translation, this practice is faced with limitations. A frequently mentioned specificity in subtitling is the spatial-temporal constraints. Beijing Opera singing shows unique rhythm and tone as well as acting. While its rhythm can be incredibly fast, it can linger on the same note for a few seconds, which is much slower than normal speeches. Accordingly, the subtitles of Beijing Opera in a film might be reasonably longer, or a single line of lyrics might be translated into two lines of subtitles. Ye (2009) also suggests adopting the same vowel in English if the source one is the slow type (拖腔, tuō qiāng, literally 'prolonged tone'). As a matter of fact, subtitling Beijing Opera for a film chiefly consists in translating the lyrics, which are, in many cases, abundant with historical, cultural and literary allusions and also allude to images of nature (Yeung, 2009: 225). Normally a maximum of two lines of subtitles appear on the screen of a film at one time, making it difficult to elaborate all the references within one or two lines of space. Hence, according to Yeung (ibid.: 226), "images that can evoke the most intense physical sensation" should be placed higher on the hierarchy concerned.

\subsection{An issue of Beijing Opera subtitling in China}

Objectively speaking, traditional Chinese Opera, due to the gap between the time of creation and translation, constitutes a remarkable challenge, which can request intralingual translation. This has been confirmed by Beijing Opera translators like Jianjun Li (Ye, 2009). Having noticed their lack of foreign language experts, Beijing Opera houses in China have hoped to train actors and other employees into translators (ibid.), but most houses still do not have full-time translators in this era. When it is necessary to translate the operas, university foreign language teachers will be approached to accomplish the task (ibid.). This still seems to be the case of the subtitling of some recent Beijing Opera films. Occasionally only subtitle supervisors instead of subtitlers are credited in those films.

It may also be worth mentioning that Beijing Opera programmes on Chinese TV channels are often presented in the form of current actors performing all the acting, including lip-synching, dubbed with recordings of late renowned artists. This presentation method is named 
音配像 (yinn pèi xiàng), literally meaning 'image matched with sound'. These programmes are equipped with Chinese subtitles in aid of audiences' interpretation and with explanations of vital moments in a smaller font running from right to left above subtitles. Because the dubbings or recordings date from decades or even a hundred years ago, laughter from the amused audience back then is often audible. In the following section, we will attempt to provide subtitles for a Beijing Opera sequence in Raise the Red Lantern (1991) while briefly examining the image and sound.

\section{Subtitling filmic Beijing Opera 御碑亭 (yù bēi tíng) / Yubei Pavilion as a case study}

Beijing Opera, as a significant form of entertainment for centuries, is also a national treasure that combines various aspects from traditional Chinese civilisation. It is a purpose-carrying element that internationally acclaimed filmmaker Zhang Yimou has involved in his Raise the Red Lantern, a film about patriarchal and Confucian hierarchy and oppression in traditional Chinese families. The film is adapted from Su Tong's novel 妻妾成群 (1991) (qi qiè chéng qún, Wives and Concubines), set in the 1920s. The major plot is this: Songlian, a 19-year-old college student, has to quit studying and marry a rich but much older man under the pressure of her stepmother. As she enters her new home as the fourth wife, she becomes aware of the vicious competition among the wives to win their husband's favour. To secure permanent care from the husband, Songlian pretends to be pregnant, only to be exposed by her maid and second wife Zhuoyun. The distraught and drunken Songlian unintentionally tells of third wife Meishan's affair with the family doctor to Zhuoyun, which soon causes Meishan to be hanged according to the family rule. The guilt from the incident and the patriarchal suffocation renders Songlian insane within a year, while the husband marries his fifth wife.

\subsection{The visual and acoustic representation of Yubei Pavilion}

Zhang Yimou took advantage of Meishan's profession as a Beijing Opera actor and inserted several opera sequences. Different scenes portray different wives' distinct moods and feelings. Some show Meishan in Beijing Opera costumes, singing in person, while others are either heard by Songlian from afar or played on a gramophone. The portrayal of her singing in person is beautiful, although she is not wearing the elaborate makeup or full accessories in a formal performance (see Figure 1). Her voice, posture, movement and demeanour can reach the audience through the visual and acoustic channels. Nevertheless, the Beijing Opera singing was not subtitled in different online or DVD versions of the film. For this, we presume three reasons. Firstly, all of the opera scenes last about one minute. Secondly, the subtitler might have assumed the meaning of the lyrics is not vital to the audience. Thirdly, subtitling an opera is more intricate than coping with normal dialogue. In the next section, we will expound the Chinese cultural specificities in one of the Beijing Opera sequences and provide a translation of the lyrics. 


\section{FIGURE 1}

Meishan sings at her courtyard

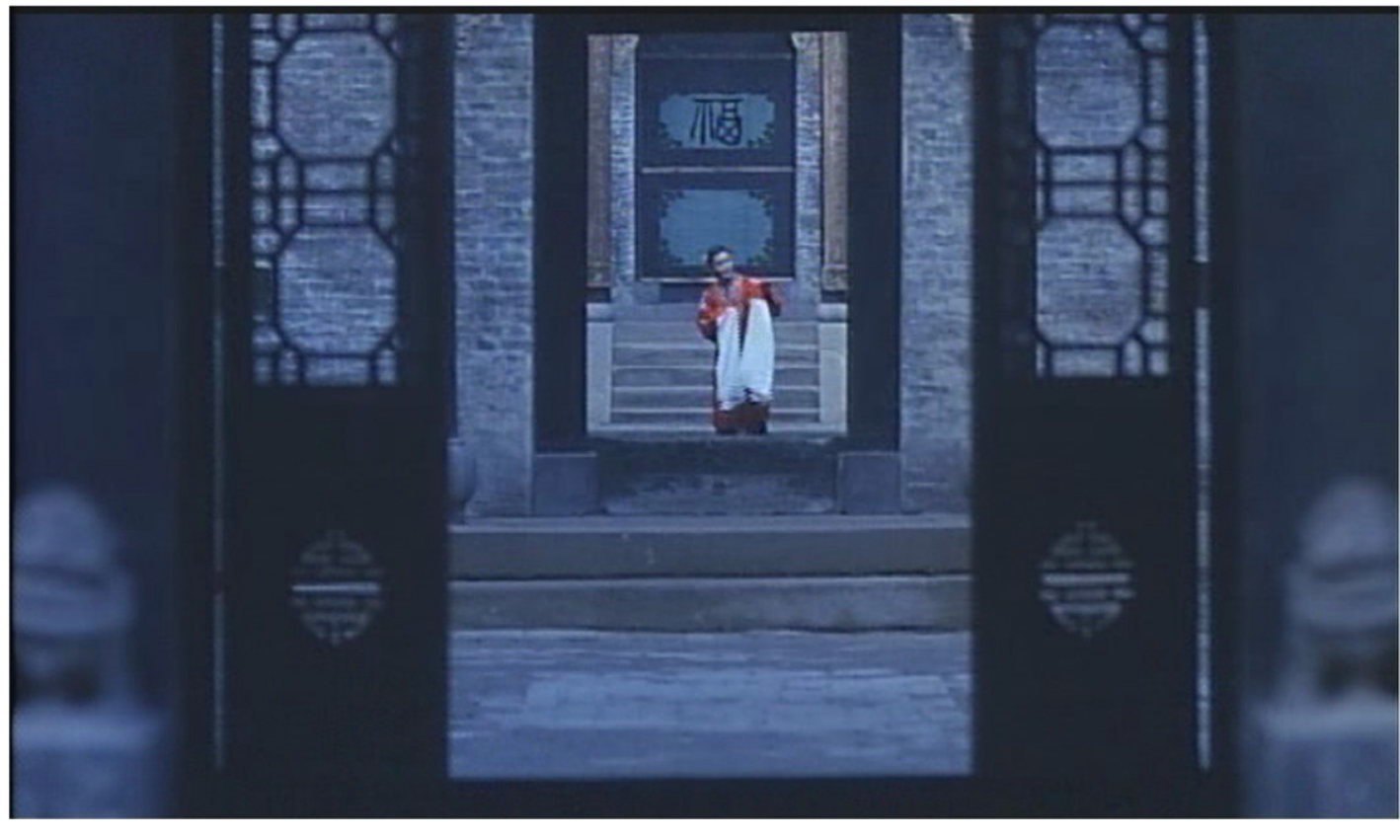

As aforementioned, Beijing Opera is a purpose-carrying element in Raise the Red Lantern. Skopos, or 'purpose' in Greek, was introduced into translation theory in the 1970s by Vermeer (1930-2010) to denote the purpose of a translation and of the action of translating (Munday, 2016: 126). Any action, before it commences, is preceded by an aim, or has prior expectations (Reiß \& Vermeer, 2014 [1984]: 85). As an interactive action between the action taker and the recipient, translation is successful if its purpose is achieved no matter how the process takes place (ibid.: 89). The paths that are taken and the strategies that are adopted are all to win a specific outcome or to serve to reach the target that was determined at the very beginning of the entire process. At the beginning of decision-making or setting the skopos, the target audience has to be assessed and certain aspects of the ST also have to be reconsidered (ibid.: 91). Like an action of translating, the filmmaker's decision to include this art form also demonstrates his purposes. Singing Beijing Opera in Raise the Red Lantern is not only a way for the third wife Meishan to cope with her boredom, to attract her husband, but also displays the filmmaker's aim to manifest the wives' emotion and, more importantly, to present the art of Beijing Opera to audiences at home and abroad.

After Songlian has Meishan murdered indirectly, she feels guilty and regretful and goes to her room and plays a recording of her previous performance on a gramophone. The lyrics are as follows: 


\section{TABLE 1}

Lyrics and the authors' translation

\begin{tabular}{|c|c|c|}
\hline $\begin{array}{l}\text { MANDARIN } \\
\text { TRANSCRIPTION }\end{array}$ & PINYIN & TRANSLATION \\
\hline 自幼父母娇生养 & zì yòu fù mŭ jiāo shēng yăng & Parents spoiled me for long. \\
\hline 盈盈十五嫁王昌 & yíng yíng shí wŭ jià wáng chāng & At 15 I married Wang Chang. \\
\hline 既读诗书不思量 & jì dú shī shū bù sī liàng & You read but don't use your mind, \\
\hline 奴岂是柳絮就随风扬 & nú qĭ shì liŭ xù jiù suí fēng yáng & imagine I go wild like cotton in wind. \\
\hline 风雨难测人难量 & fēng yŭ nán cè rén nán liàng & $\begin{array}{l}\text { Storms hard to predict, people } \\
\text { hard to understand. }\end{array}$ \\
\hline 暗室何必日月光 & àn shì hé bì rì yuè guāng & No sunlight shines through a dark house. \\
\hline 阴谋毒计良心丧 & yīn móu dú jì liáng xīn sàng & Heartless husband lost his conscience. \\
\hline 休书好比杀人场 & xiū shū hǎo bì shā rén chǎng & Divorce paper made one hopeless. \\
\hline 手摸胸膛想一想 & shŏu mō xiōng táng xiăng yì xiăng & Look into yourself, think it over. \\
\hline 无义的王魁比你强 & wú yì de wáng kuí bĭ nĭ qiáng & Immoral Wang Kui is better than you are! \\
\hline
\end{tabular}

This piece is from 御碑亭 (yù bei tíng, Yubei Pavilion)1, but is edited and the rhythm is quickened. The story goes as young wife Yuehua Meng shelters from rain at Yubei Pavilion on her way home. Later, a young scholar Shengchun Liu also stops by the pavilion, but politely stands outside without disturbing Meng. Sadly, when Meng's husband Wang hears of the two "sharing" the same pavilion, he suspects Meng has cheated on him and divorces her with a scheme. The piece which demonstrates Meng being resentful and heart-broken when her husband begs for forgiveness conspicuously correlates with Meishan being found unfaithful in the film.

In this sequence, Beijing Opera begins to play in Meishan's room. As she has been killed and her room shut and lanterns covered up, servants reckon that it is Meishan's ghost singing. When they enter the room, the eerie red light of all the lanterns and massive Beijing Opera masks make them more scared and run out (see Figure 2). Then the camera returns to her room and finds Songlian blowing off a lighter. A long shot focuses on Meishan's bed, while all the lanterns on the tables and on the ceiling draw our attention again. The costume on the far side of the room is even placed in the shape of a dummy person. Then the camera moves outside to the yard but slowly zooms back in through the door of the room, and finally closes up on Songlian's face, which looks young and beautiful but numb and expressionless.

$1 \quad$ Ma Lianliang's version was produced in around 1931. 
The visual effect, such as the eerie red light in the room, can be associated with the lyric "No sunlight shines through a dark house". Meanwhile, the sound effect renders Meishan's solo like a chorus, which expresses the fury and protest in the lyrics more evidently, as if multiple singers are voicing the two women's feelings.

\section{FIGURE 2}

The red lanterns in Meishan's room are lit again

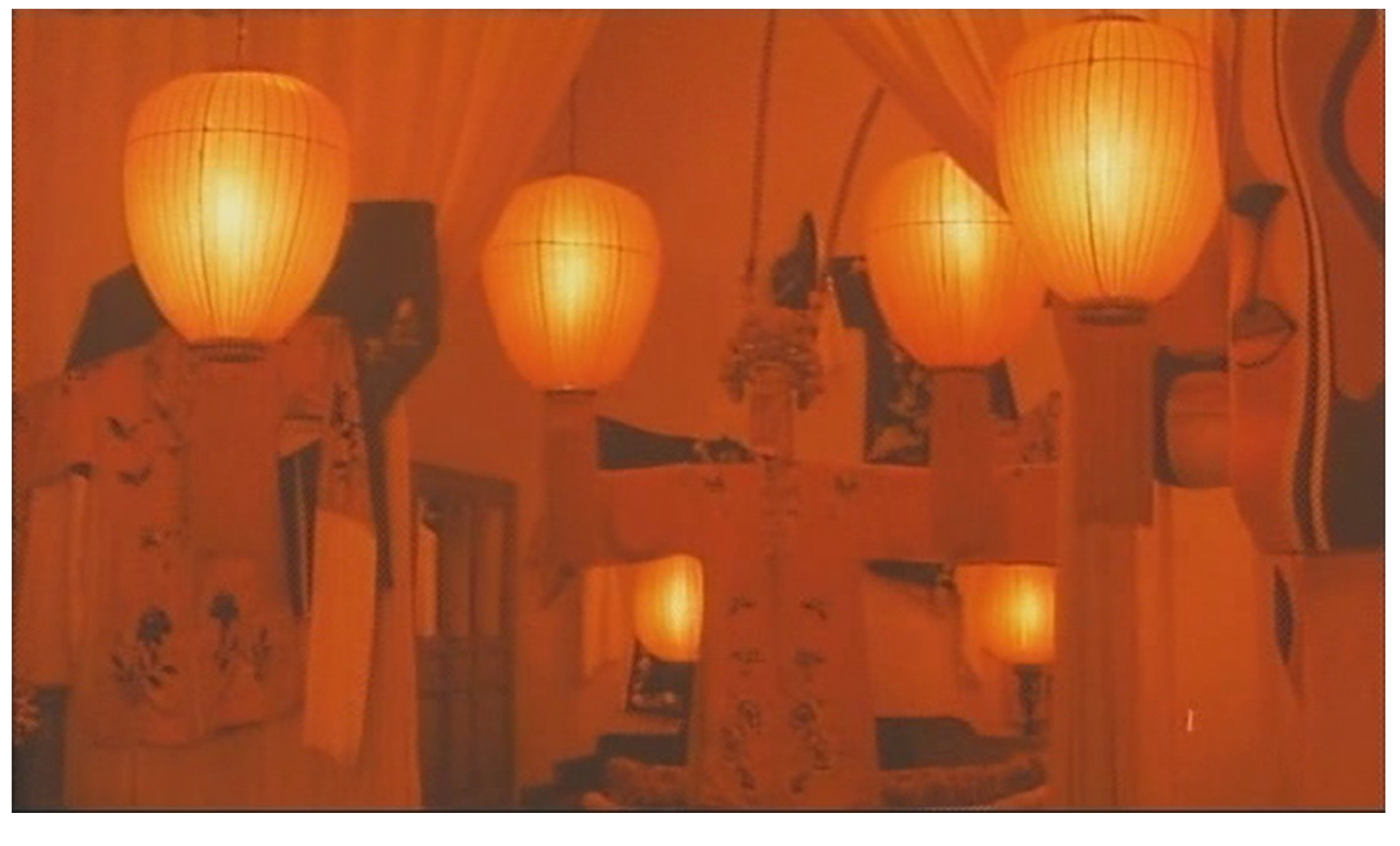

\subsection{Analysis of the lyrics and the strategy in translating them}

As is manifested in the story of Yubei Pavilion, during the last two centuries, Beijing Opera has absorbed and reflected traditional values (Guo, 2012: 52). Confucianism and Daoism, two leading sources of Chinese values and thoughts in thousands of years, have infiltrated literature and art works as well as Beijing Opera (ibid.). Patriotism, righteousness, diligence and honesty have become Chinese people's ideal virtues, which are reflected in Beijing Opera (ibid.). In ancient China, women had to keep a distance from men in general. The Confucian classic 孟 子 (mèng žl, Mencius) advocated “男女授受不亲”, which means men and women should not give or receive things in their own hands. In the opera, “奴岂是柳絮就随风扬” literally means “I am not catkins that go wild with wind”. “柳絮” (liŭ xü) is catkins, the cotton-like flowers of willow trees, which are easily blown away by the wind, which metaphorically indicates women's changeability and easy virtue. The next lines “风雨难测人难量, 暗室何必日月光” (Storms hard to predict, people hard to understand. No sunlight shines through a dark house) literally imply that a husband can be as unpredictable as the weather and can lose his trust easily. 
When proposing subtitles for this piece, simplification, one of the "universals of translation" (Baker, 1993: 243), is hard to avoid. The postulated universals of translation are 'features that typically occur in translated texts rather than original utterances and which are not the result of interference from specific linguistic systems' (ibid.). Based on corpus research, translated texts between various language pairs are often proved to show a tendency towards simplification, the evidence of which includes more precise identification, simpler syntax, less lexical variety, lower lexical density and more use of high-frequency items (Vanderauwera, 1985, quoted in ibid.; Laviosa-Braithwaite, 1996, quoted in Chesterman, 2004: 8; Xiao, 2010: 29). Thus, simplification can be a valid translation strategy in coping with transferring Beijing Opera into English. Take “盈盈十五” (yíng yíng shi wŭ) as an example. “盈盈” generally has three meanings, clear (water), elegant (gait) and poor digestion (Sources of rhetoric Editorial Team \& The Commercial Press Editorial Board, 1987: 2185; Ocean of rhetoric Editorial Board, 1999: 4791). It contextually refers to Meng's beauty and elegance when she gets married at the age of 15 . As the opera has not been subtitled in the referenced version, all references end up being domesticated and omitted. Subtitle readers can only observe the visuality while endeavouring to imagine the meaning of the lyrics by interactive and dynamic film-watching. Even if 盈盈十五 were translated, it might have to be reduced into "at the age 15". As the opera voices fury and is sung fast, the sentence structures of English subtitles may also have to be simplified with functional and grammatical words omitted as in Yeung's (2009: 225) suggestion.

Although simplification is essential, audiences can still benefit from simplified subtitles, which are more helpful than complete omission, as they can correlate the image, sound and plot context more thoroughly. As Matamala and Remael (2014: 4) mention, film audiences receive both visual and aural input which is integrated into their previous world and filmic knowledge and mental representations in constructing the filmic story in their minds. After all, lyrics do not constitute the sole source of information in such a viewing experience. As an opera is a multimodal entity (Bosseaux, 2011: 193), subtitle readers' dynamic film-watching enables them to receive visual and acoustic information from film characters' acting as well as singing. Occasionally non-verbal information, such as body language, compensates for certain verbal information which is lost in translation (Yuan, 2018: 148). Yet, compared to simplification, completely omitting a Beijing Opera leads to the loss of all the cultural particularities, which is not the best solution.

The strategy of simplification, which is inescapable in the subtitling of Yubei Pavilion, can also be juxtaposed with contemplation on "Skopos". Low (2002: 109) argues that the best approach for devising opera surtitles is based on Skopos, i.e." "the specific purpose and function of the TT (target text) must govern the decisions taken". A translational action does not only focus on linguistics, but is rather a cultural transfer process that includes a linguistic transfer (Reiß \& Vermeer, 2014 [1984]: 113). In a multisemiotic complex such as Beijing Opera, words are not the sole ST to be translated, but the visual, acoustic and cultural are not to be excluded. 
Strictly speaking, any element loss causes a translational action to fail, but simplification which preserves to some extent the intercommunication between the operatic semiotics, still has its own merits. The strategy of simplification is not only essential in subtitling filmic Beijing Opera but also surtitling opera in general due to the multisemiotic characteristic of the operatic art form and the skopos to provide unobtrusive surtitles.

\section{Conclusion}

Existing research in opera translation primarily concentrates on operas in the western countries and opera translation for the stage. In comparison, this paper, by taking Beijing Opera and a sequence in Zhang Yimou's Raise the Red Lantern as an example, has re-examined the practice of opera translation and surtitling. In the process, by attempting to translate one of the opera scenes, we analysed Beijing Opera subtitling in a film. It can be seen that simplification is an indispensable strategy in its rendition owing to the prevalent existence of Chinese allusions, idioms, proverbs and other specific elements. Although particular cultural specificities may not survive the process of translation, translating Beijing Opera displays a respectful attitude to the filmmaker's decision to include it as well as to its actors and creators.

This study, due to space limit, has analysed Beijing Opera singing in only one of the sequences in the film. This film also encompasses other Beijing Opera sequences which could be examined and translated. Moreover, other films have been made in recent years which also showcase Beijing Opera singing. Research on those films will unquestionably enrich the literature on the translation of Beijing Opera. Another limitation is that this study is solely based on qualitative analysis. Thus, it will be more fruitful to build a corpus of the ST of Beijing Opera lyrics and a comparative corpus of the back-translation of English subtitles in order to compare the two corpora to find the differences and seek for answers for such disparities.

In the past few decades, at least 50 Beijing Opera-related films have been made, some of which are deliberately made for international audiences to showcase this art form. Thus, it will be beneficial to investigate how culturally-bound references have been rendered into English in those films, maybe through corpus research. In the future, as is predicted by Low (2002: 109), there may be more and more opera houses with titles for international viewers; maybe every viewer will have access to a screen for titles in front of them which can also be switched on or off by choice and with titles in various foreign languages.

\section{Acknowledgements}

This research has received financial support from a research fund (090500512018 / 2018G02) of Zhejiang International Studies University. 


\section{Bibliographic references}

BAKER, Mona, 1993: "Corpus linguistics and translation studies: Implications and applications" in Mona Baker, Giles Francis \& Elena Tognini-Bonelu (eds.): Text and Technology: In Honour of John Sinclair, Amsterdam: John Benjamins: 233-250.

BASSnetT, Susan, 2002 [1980]: Translation Studies, third edition, New York: Routledge.

BASSNETt, Susan, 1998: "Still trapped in the labyrinth: Further reflections on translation and theatre" in Susan BAsSnetT \& Andre LefEVERE (eds.): Constructing Cultures - Essays on Literary Translation, Clevedon: Multilingual Matters: 90-108.

Batalllon, Michel, 2017: "Faust I \& II. Chronique d'un sur-titrage” [Faust I \& II. Chronicle of surtitling], Meta 62 (3), 624-633.

Batalllon, Michel, Laurent Muhleisen \& Pierre-Yves Diez, 2016: Guide du sur-titrage au théâtre [A Guide of Theatre Surtitling], Paris: Maison Antoine Vitez.

Bosseaux, Charlotte, 2011: "The translation of song" in Kirsten MalmkJÆR \& Kevin Windle (eds.): The Oxford Handbook of Translation Studies, Oxford: Oxford University Press: 183-197.

BURTON, Jonathan, 2010: "The joy of opera: The art and craft of opera subtitling and surtitling" in Łukasz Boguckı \& Krzysztof Kredens (eds.): Perspectives on Audiovisual Translation, Basingstoke: Palgrave Macmillan: 179-188.

CAO, Guangtao, 2011a: “传统戏曲英译的翻译规范刍议” [A study on the norms of English translation of traditional Chinese opera], Translations (Academic Edition) 10, 141-152.

CAO, GuangtaO, 2011b: “基于演出视角的京剧英译与英语京剧” [English translation research of the Beijing Opera based on performance and English Beijing Opera], Journal of Jishou University (Social Sciences Edition) 32 (06), 158-162.

CAO, GuangtaO, 2015: “译者的归译者, 导演的还给导演”一一基于戏曲视角的可表演性翻译原 则限度分析” [On the limitation of performability of drama translation from the perspective of traditional Chinese opera], Foreign Language and Literature (bimonthly) 31 (1), 126-132.

Chesterman, Andrew, 2004: "Hypotheses about translation universals" in Gyde Hansen, Kirsten MalmkJer \& Daniel GIle (eds.): Claims, Changes and Challenges in Translation Studies, Amsterdam: John Benjamins: 1-13.

CHIU, Fusheng (producer), \& Yimou ZHANG (director), 2007: Raise the Red Lantern [DVD], China: Zoke Culture. 
Christiansen, Rupert, 2005, June 15th: "The arts column: Why we have to learn how to love surtitles", The Telegraph [https://www.telegraph.co.uk/, date of retrieval: May 3rd, 2018].

Desblache, Lucile, 2019: Music and Translation: New Mediations in the Digital Age, Basingstoke: Palgrave Macmillan.

Dewolf, Linda, 2001: "Surtitling operas. With examples of translations from German into French and Dutch" in Yves Gambier \& Henrik Gottlieb (eds.): (Multi)Media Translation. Concepts, Practices, and Research, Amsterdam: John Benjamins: 179-188.

Dong, Dan, 2017: “京剧《锁麟囊》剧本译介的几点思考” [Thoughts on the translation and international introduction of Beijing Opera The Jewellery Purse], Art Research 03, 134-135.

Gorlée, Dinda L., 1996: “Opera translation: Charles Peirce translating Richard Wagner” in Eero TARAsti, Paul Forsell \& Richard Littlefield (eds.): Musical Semiotic in Growth, Bloomington: Indiana University Press: 407-436.

Griesel, Yvonne, 2009: "Surtitling: Surtitles an other hybrid on a hybrid stage", Revista de Traductología 13, 119-127.

Guo, Suihong, 2012: “京剧行当翻译中的文化传递” [Cultural transmission in translating role categories and schools of the Beijing Opera], Journal of Huizhou University (Social Sciences Edition) 32 (5), 51-55.

HuAnG, Xiaoju, 2002, March gth: “得不偿失” [What is gained cannot repay the loss], Chinese Cultural Newspaper [http://www.cnki.net/, date of retrieval: March 19th, 2018].

Ladouceur, Louise, 2013: "Surtitles take the stage in Franco-Canadian theatre", Target 25 (3), 343-364.

Low, Peter, 2002: "Surtitles for opera: A specialised translating task”, Babel 48 (2), 97-110.

LUNDEN, Jeff, 2018, January 21st: "Read 'em and weep: Celebrating 35 years of opera supertitles" [https://www.npr.org/sections/deceptivecadence/2018/01/21/578663092/read-emand-weep-celebrating-35-years-of-opera-supertitles?t=1531681686540, date of retrieval: June 8th, 2018].

Matamala, Anna, \& Aline Remael, 2014: "Audio-description reloaded: An analysis of visual scenes in 2012 and Hero", Translation Studies 8 (1), 63-81.

Mateo, Marta, 2007: "Surtitling today: New uses, attitudes and developments", Linguistica Antverpiensia 6, 135-154. 
Mencius, 2017: 孟子 [Mencius], Yong FAng, translated, Beijing: Zhonghua Book Company.

Munday, Jeremy, 2016 [2001]: Introducing Translation Studies: Theories and Applications, fourth edition, London: Routledge.

Ocean of Rhetoric EdITORIAL BOARD, 1999: 辞海 [Ocean of Rhetoric], Shanghai: Shanghai Lexicographical Publishing House.

Oncins, Estela, 2013: "The tyranny of the tool: Surtitling live performances", Perspectives: Studies in Translatology 23 (1), 42-61.

Orero, Pilar, \& Anna Matamala, 2007: "Accessible opera: Overcoming linguistic and sensorial barriers", Perspectives: Studies in Translatology 15 (4), 262-277.

PAGE, Jacqueline, 2013: "Surtitling opera: A translator's perspective” in Helen Julia MinoRs (eds.): Music, Text and Translation, London: Bloomsbury: 35-47.

PALMER, Judi, 2013: "Surtitling opera: A surtitler's perspective on making and breaking the rules" in Helen Julia Minors (eds.): Music, Text and Translation, London: Bloomsbury, 21-33.

Pridmore-Franz, Milane, 2015: "La pratique du surtitrage en contexte minoritaire" [The practice of surtitling in a minority context], Convergences francophones [Francophone Convergences] 2 (2), 57-67.

RęDzioch-Korkuz, Anna, 2018: “Constraints on opera surtitling: Hindrance or help?”, Meta 63 (1), 216-234.

Relss, Katharina, \& Hans J. Vermeen, 2014 [1984]: Towards a General Theory of Translational Action: Skopos Theory Explained, Christiane Nord, Translated, Oxon: Routledge.

SCORCIA, Antonia Mele, 2018: "Surtitling and the audience: A love-hate relationship", The Journal of Specialised Translation 30, 181-202.

Sources of Rhetoric Editorial Team \& the Commercial Press Editorial Board, 1987: 辞源 [Sources of Rhetoric], Beijing: The Commercial Press.

Su, Tong, 1991: 妻妾成群 [Wives and Concubines], Guangzhou: City of Flowers Publishing House.

The Metropolitan Opera, 2019: "Met Titles" [https://www.metopera.org/about/faq/met-titles/, date of retrieval: August 22nd, 2019].

VIRKKUnen, Riitta, 2004: "The source text of opera surtitles", Meta 49 (1), 89-97. 
WANG, Yuzhen, 1985: “旅欧演出散记” [On performing in Europe], Opera Newspaper 12, 51-52.

XIAO, Richard, 2010: "How different is translated Chinese from native Chinese? A corpus-based study of translation universals", International Journal of Corpus Linguistics 15 (1), 5-35.

XIAO, Weiqing, \& Xianguan XIONG, 2016: “两百余载薪火旺 新凤又胜老凤声” [New developments in translating Beijing Opera], Hundred Schools in Arts 32 (05), 168-173.

YE, Fei, 2009, April 1st: “京剧的不可言说之痛” [The unspeakable hardship of Beijing Opera], Chinese Cultural Newspaper [http://www.cnki.net/, date of retrieval: August 20th, 2018].

YeUnG, Jessica W. Y., 2009: "Subtitling for Xiqu (Chinese Opera) in the theatre" in Gilbert C. F. Fong \& Kenneth K. L. Au (eds.): Dubbing and Subtitling in a World Context, Hong Kong: Chinese University Press: 221-230.

Yuan, Yilei, 2018: "Politeness in subtitling: To retain or not to", Studia Translatorica 8, 137-150.

ZHANG, Linlin, 2013: “从“青衣”等京剧术语的英译看文化翻译的归化和异化” [On domestication and foreignisation in cultural translation through the Beijing Opera terms like 'Qing Yi'], Shanghai Journal of Translators 04, 41-43.

ZHu, Yuan, 2006: “从《李笠翁曲话》英译看汉语典籍英译” [On the English translation of Li Yu's essays on classical drama], Foreign Languages and Their Teaching 04, 48-51.

\section{Glossary}

孟子: Mencius

男女授受不亲: Men and women should not give or receive things in their own hands.

奴岂是柳絮就随风扬: I am not catkins that go wild with wind.

柳絮: catkins

风雨难测人难量, 暗室何必日月光: Storms hard to predict, people hard to understand. No sunlight shines through a dark house.

盈盈: clear (water); elegant (gait); poor digestion

十五: fiveteen 